Gozhenko A. I., Levitsky A. P., Stepan V. T., Selivanskaya I. A., Pustovoit I. P. Comparative nephroprotective efficiency of polyfunctional mucous-adhesive phytogels. Journal of Education, Health and Sport. 2021;11(1):24-32. eISSN 2391-8306. DOI http://dx.doi.org/10.12775/JEHS.2021.11.1.002

https://apcz.umk.pl/czasopisma/index.php/JEHS/article/view/JEHS.2021.11.1.002

https://zenodo.org/record/4421703

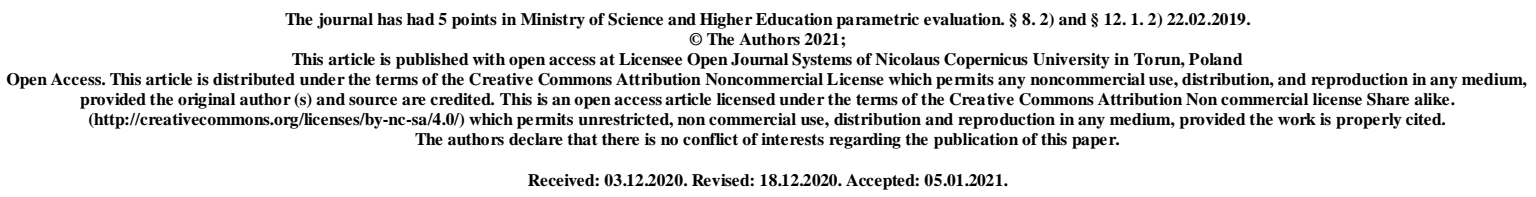

UDK 615.07:615.015:616.98

\title{
COMPARATIVE NEPHROPROTECTIVE EFFICIENCY OF POLYFUNCTIONAL MUCOUS-ADHESIVE PHYTOGELS
}

\author{
A. I. Gozhenko ${ }^{1}$, A. P. Levitsky ${ }^{2}$, V. T. Stepan ${ }^{3}$, I. A. Selivanskaya ${ }^{4}$, \\ I. P. Pustovoit ${ }^{5}$
}

\section{${ }^{1}$ Ukrainian Research Institute of Transport Medicine of the Ministry of Health of Ukraine, Odessa \\ ${ }^{2}$ Odessa National Academy of Food Technologies \\ ${ }^{3}$ Bukovina State Medical University, Chernovtsy \\ ${ }^{4}$ Odessa National Medical University \\ ${ }^{5}$ Municipal Institution «Odessa Regional Clinical Hospital»}

\begin{abstract}
Aim. To compare the nephroprotective effect of oral applications of different phytogels in experimental kidney pathology.

Methods. We used phytogels: "Kvertulin" (quercetin + inulin + calcium citrate), "Biotrit" (juice from wheat germ) and "Dubovy" (extract from oak wood).

Experimental models were reproduced in rats: diabetic syndrome, prednisolone immunodeficiency, intoxication with thermal peroxide sunflower oil. The condition of the kidneys was assessed by changes in the level of biochemical markers in the kidney tissue (elastase, urease, lysozyme, MDA, the degree of dysbiosis).
\end{abstract}


Results. Experimental pathologies cause an increase in the level of elastase, urease, MDA, the degree of dysbiosis, and a decrease in lysozyme activity in the kidneys. Oral application of phytogels caused a decrease in the activity of elastase, urease, MDA content and the degree of dysbiosis, but increased the activity of lysozyme. When recalculating the degree of decrease in elastase activity and increase in lysozyme activity per $1 \mathrm{~g}$ of phytogel or $1 \mathrm{mg}$ of active principle (quercetin or the amounts of polyphenols), phytogel "Kvertulin" turned out to be the most effective anti-elastase agent, and phytogel "Biotrit" turned out to be the most effective lysozyme-reducing agent.

Conclusion. Oral applications of multifunctional mucous-adhesive gels have a nephroprotective effect in experimental kidney pathology.

Key words: kidney; nephroprotection; phytogels; stomatotropic therapy; quercetin; plant polyphenols.

\section{INTRODUCTION}

In our previous work, it was shown that the oral cavity can cause nephropathy. Therefore, the use of therapeutic and prophylactic agents by oral applications provides a certain nephroprotective effect [1-4]. It is known that the oral cavity is one of the most important habitats of the body, the number of microbes second only to the large intestine [5, 6]. But in contrast to the intestine, microbes and toxins which enter the blood are delayed (neutralized) by the liver [7], in the oral cavity microbes and their toxins entering the blood easily reach the kidneys. The aim of this work was a comparative study of the nephroprotective effect of three mucous-adhesive phytogels with bioflavonoids, which have antioxidant, prebiotic, angioprotective, anti-inflammatory activity, namely the phytogel "Kvertulin", which includes [bioflavonoid 8] quercetin ] and calcium citrate [9], phytogel "Biotrit", which includes juice from wheat germ, vitamin C, prebiotic inulin [10] and phytogel "Dubovy", which includes extract "Dubovy", containing phenolic compounds from oak wood [11].

Dysbiotic syndrome [3], thermoperoxide sunflower oil (TPSO) intoxication [1] and prednisolone-induced immunodeficiency were chosen as models of nephropathy [12].

Determination of the activity of elastase, urease, lysozyme and the content of MDA (malonic dialdehyde) was chosen as markers of pathological processes in the kidneys [13]. 


\section{MATERIAL AND RESEARCH METHODS}

Mucous-adhesive phytogels produced by the SPA "Odessa Biotechnology" were used in the work (Table 1).

Table 1 - Characteristics of the gel forms of polyfunctional antidisbiotic drugs (PFAD)

\begin{tabular}{|c|c|c|}
\hline Name PFAD & $\begin{array}{l}\text { The composition of the gel per } \\
\qquad 1 \mathrm{ml}\end{array}$ & Regulatory documentation \\
\hline $\begin{array}{l}\text { Kvertulin } \\
\text { The content of } \\
\text { polyphenols } \\
\text { (quercetin) is } \\
5 \mathrm{mg} / \mathrm{ml}\end{array}$ & $\begin{array}{c}\text { Quercetin - } 5 \mathrm{mg} \\
\text { Vitamin C - } 3 \mathrm{mg} \\
\text { Inulin - } 20 \mathrm{mg} \\
\text { Citrate Ca }-5 \mathrm{mg} \\
\text { Mint extract } 10 \%-0.1 \mathrm{ml} \\
\text { Sodium benzoate }-10 \mathrm{mg} \\
\text { Na-CMC - } 40 \mathrm{mg}\end{array}$ & $\begin{array}{c}\text { TU U 20.4-13903778-032:2012 } \\
\text { RC U 20.4-13903778-032/1:2012 } \\
\text { Conclusion of the Ministry of } \\
\text { Health № 05.03.02-07/5025 dated } \\
\text { 05.02.2013 }\end{array}$ \\
\hline $\begin{array}{l}\text { Biotrit } \\
\text { The content of } \\
\text { polyphenols } \\
5 \mathrm{mg} / \mathrm{ml}\end{array}$ & $\begin{array}{l}\text { Wheat germ juice }-0.2 \mathrm{ml} \\
\text { Vitamin } \mathrm{C}-3 \mathrm{mg} \\
\text { Inulin }-20 \mathrm{mg} \\
\text { Citrate } \mathrm{Ca}-5 \mathrm{mg} \\
\text { Mint extract } 10 \%-0.1 \mathrm{ml} \\
\text { Sodium benzoate }-10 \mathrm{mg} \\
\text { Na-CMC - } 40 \mathrm{mg}\end{array}$ & $\begin{array}{c}\text { TU U 20.4-13903778-032:2012 } \\
\text { RC U 20.4-13903778-032/4:2014 } \\
\text { Conclusion of the Ministry of } \\
\text { Health № 05.03.02-07/43417 dated } \\
\text { 03.07.2014 }\end{array}$ \\
\hline $\begin{array}{l}\text { Dubovy } \\
\text { The content of } \\
\text { polyphenols } \\
5 \mathrm{mg} / \mathrm{ml}\end{array}$ & $\begin{array}{c}\text { Oak extract }-0.2 \mathrm{ml} \\
\text { Mint extract } 10 \%-0.1 \mathrm{ml} \\
\text { Sodium benzoate }-20 \mathrm{mg} \\
\mathrm{Na}-\mathrm{CMC}-40 \mathrm{mg}\end{array}$ & $\begin{array}{c}\text { TU U 10.8-13903778-032:2012 } \\
\text { RC U 20.4-13903779-032/13:2017 } \\
\text { Conclusion of the Ministry of } \\
\text { Health № 602-123-20-2/11705 } \\
\text { dated 20.04.2017 }\end{array}$ \\
\hline
\end{tabular}

Biological studies were performed on 79 white Wistar rats $(220-350 \mathrm{~g})$ in three series: 1 - with dysbiotic syndrome [3], 2 - with TPSO toxicity [2] and 3 - with experimental immunodeficiency (Table 2) [12].

Table 2 - Experimental series of experiments

\begin{tabular}{|c|l|c|c|}
\hline №№ & \multicolumn{1}{|c|}{ Series } & $\begin{array}{c}\text { The method of reproduction of } \\
\text { pathology }\end{array}$ & $\begin{array}{c}\text { Number of } \\
\text { animals }\end{array}$ \\
\hline 1 & $\begin{array}{l}\text { Dysbiotic syndrome and } \\
\text { phytogel "Kvertulin" }-1 \mathrm{ml} / \mathrm{kg} \\
\text { from the 7th to the 10th day }\end{array}$ & $\begin{array}{c}\text { Lincomycin with drinking water } \\
60 \mathrm{mg} / \mathrm{kg}, 5 \text { days. Epinephrin in } \\
\text { the form of a gel } 0.18 \mathrm{mg} / \mathrm{kg}, \\
3 \text { days }\end{array}$ & 21 \\
\hline 2 & $\begin{array}{l}\text { TPSO intoxication and Biotrit } \\
\text { phytogel }-1.5 \mathrm{ml} / \mathrm{kg}, 5 \text { days }\end{array}$ & $\begin{array}{c}\text { Oral applications of TPSO } \\
1.5 \mathrm{ml} / \mathrm{kg} \text { for } 5 \text { days }\end{array}$ & 18 \\
\hline 3 & $\begin{array}{l}\text { Immunodeficiency and phytogels } \\
\text { "Kvertulin", "Biotrit", "Duboy" } \\
1 \mathrm{ml} / \mathrm{kg}, 20 \text { days }\end{array}$ & $\begin{array}{c}\text { Prednisolone intragastrically } \\
10 \mathrm{mg} / \mathrm{kg} \text { for } 2 \text { days, then } \\
5 \mathrm{ml} / \mathrm{kg} \text { for } 17 \text { days }\end{array}$ & 40 \\
\hline
\end{tabular}


In the first series of experiments, rats received with drinking water the antibiotic lincomycin at a dose of $60 \mathrm{mg} / \mathrm{kg}$ for the first 5 days, and then adrenaline by oral administration at a dose of $0.18 \mathrm{mg} / \mathrm{kg}$ for 3 days. Oral applications of phytogel "Kvertulin" were done daily at a dose of $1 \mathrm{ml} / \mathrm{kg}$ for the last 3 days. Euthanasia of rats was performed on the 10th day of the experiment. The activity of urease [13], lysozyme [13] was determined in the blood serum, and the degree of dysbiosis was calculated by the ratio of their relative activities [13].

The same parameters were determined in the homogenate of the kidneys, as well as in the kidneys determined the level of biochemical markers of inflammation, namely the activity of elastase [13] and the content of MDA [13].

In the second series of experiments, the intoxication of rats was reproduced by the consumption of thermoperoxide sunflower oil (TPSO) by oral administration of TPSO at a dose of $1.5 \mathrm{ml} / \mathrm{kg}$ daily for 5 days. In the experimental group, 30 minutes before the application of TPSO, the phytogel "Biotrit" was administered at a dose of $1.5 \mathrm{ml} / \mathrm{kg}$. After euthanasia of animals on the 6th day in the kidney homogenate determined the activity of urease, lysozyme, elastase, MDA content and calculated the degree of dysbiosis.

In the third series of experiments on 40 rats examined the condition of the kidneys of rats with experimental immunodeficiency (ID), which was reproduced with prednisolone, which was administered per os at a dose of $10 \mathrm{mg} / \mathrm{kg}$ (first 2 days) and at a dose of $5 \mathrm{mg} / \mathrm{kg}$ days). All animals were divided into 5 equal groups: 1st - control, 2nd received TPSO, 3rd received TPSO + oral applications of phytogel "Kvertulin", 4rd - TPSO + phytogel "Biotrit", 5 th - TPSO + phytogel "Dubovy". Oral applications of phytogels were done daily from day 1 to day 19 inclusive at a dose of $1 \mathrm{ml} / \mathrm{kg}$.

After euthanasia of the animals on the 20th day, the activity of urease and lysozyme was determined in the blood serum and the degree of dysbiosis was calculated, and the activity of urease, lysozyme, elastase and MDA content was determined in the kidney homogenate and the degree of dysbiosis was calculated.

Statistical processing of the results was carried out by standard methods $(\mathrm{M} \pm \mathrm{m}, \mathrm{p})$ [14].

\section{RESULTS AND DISCUSSION}

Table 3 presents the results of determining the biochemical parameters in the serum of rats in which reproduced dysbiotic syndrome (DS). It is seen that significantly increases the activity of urease, which indicates an increase in bacterial contamination (bacteremia), and the 
activity of lysozyme, on the contrary, decreases, which indicates a decrease in the level of nonspecific immunity. As a result, the degree of dysbiosis increases almost 4 times.

In the serum of rats with DS, which received oral applications of the phytogel "Kvertulin", urease activity is reduced, lysozyme activity is significantly increased and as a result the degree of dysbiosis is almost halved.

In the kidneys of rats with dysbiotic syndrome, the level of urease and lysozyme changes slightly, but the degree of dysbiosis increases significantly. In rats treated with phytogel "Kvertulin", lysozyme activity increases and the degree of dysbiosis is significantly reduced.

In rats with dysbiotic syndrome in the kidneys significantly increases the level of inflammatory markers (elastase and MDA), but applications of the phytogel "Kvertulin" normalize these indicators.

Table 3 - Biochemical parameters of the condition of rats with dysbiotic syndrome (DS), which received oral applications of phytogel "Kvertulin"

\begin{tabular}{|l|c|c|c|}
\hline \multirow{2}{*}{\multicolumn{1}{|c|}{ Indicators }} & \multicolumn{3}{|c|}{ Groups } \\
\cline { 2 - 4 } & $1-$ Control & $2-\mathrm{DS}$ & $3-\mathrm{DS}+$ "Kvertulin" \\
\hline Blood Serum: & & & $0,12 \pm 0,02$ \\
& $0,06 \pm 0,01$ & $0,15 \pm 0,03$ & $\mathrm{p}<0,05 ; \mathrm{p}_{1}>0,3$ \\
\hline Urease, mk-cat/l & & $\mathrm{p}<0,005$ & $100 \pm 7$ \\
& $107 \pm 8$ & $73 \pm 5$ & $\mathrm{p}>0,3 ; \mathrm{p}_{1}<0,05$ \\
\hline Lysozyme, units/liter & & $\mathrm{p}<0,05$ & $2,00 \pm 0,23$ \\
dye degree of & $1,00 \pm 0,17$ & $\mathrm{p}, 87 \pm 0,42$ & $\mathrm{p}<0,05 ; \mathrm{p}_{1}<0,01$ \\
\hline Kidneys: & & & $0,24 \pm 0,10$ \\
\hline Urease, $\mu$-cat/kg & $0,17 \pm 0,08$ & $0,30 \pm 0,10$ & $\mathrm{p}>0,3 ; \mathrm{p}_{1}>0,3$ \\
\hline Lysozyme, units/kg & $8010 \pm 686$ & $7847 \pm 399$ & $9846 \pm 629$ \\
& & $\mathrm{p}>0,3$ & $\mathrm{p}>0,05 ; \mathrm{p}_{1}<0,05$ \\
\hline The degree of & $1,00 \pm 0,20$ & $1,76 \pm 0,28$ & $0,87 \pm 0,11$ \\
dysbiosis & & $\mathrm{p}<0,05$ & $\mathrm{p}>0,3 ; \mathrm{p}_{1}<0,05$ \\
\hline Elastase, $\mu$-cat/kg & $440 \pm 70$ & $790 \pm 170$ & $400 \pm 160$ \\
& & $\mathrm{p}<0,05$ & $\mathrm{p}>0,5 ; \mathrm{p}_{1}>0,05$ \\
\hline MDA, mmol/kg & $35,5 \pm 1,2$ & $41,9 \pm 1,9$ & $37,1 \pm 1,4$ \\
& & $\mathrm{p}<0,05$ & $\mathrm{p}>0,3 ; \mathrm{p}_{1}<0,05$ \\
\hline
\end{tabular}

Notes: $\mathrm{p}$ - in comparison with gr. $1 ; \mathrm{p}_{1}-$ in comparison with gr. 2 .

Table 4 presents the results of determining the biochemical parameters of the kidneys of rats treated with TPSO. It is seen that rats treated with TPSO significantly increased the 
level of urease, elastase and MDA and the degree of dysbiosis, but significantly reduced lysozyme activity.

Oral applications of Phytogel Biotrit almost completely normalize all biochemical parameters (except for the content of MDA).

Table 4 - Biochemical parameters of the kidneys of rats treated with thermoperoxide sunflower oil (TPSO) and oral applications of phytogel "Biotrit"

\begin{tabular}{|l|c|c|c|}
\hline \multirow{2}{*}{ Indicators } & \multicolumn{3}{|c|}{ Groups } \\
\cline { 2 - 4 } & $1-$ control & $2-$ TPSO & $3-$ TPSO+«Biotrit» \\
\hline Urease, $\mu$-cat/kg & $0,73 \pm 0,02$ & $0,83 \pm 0,03$ & $0,74 \pm 0,05$ \\
& & $\mathrm{p}<0,05$ & $\mathrm{p}>0,3 ; \mathrm{p}_{1}>0,05$ \\
\hline Lysozyme, units/kg & $2416 \pm 330$ & $1343 \pm 330$ & $2430 \pm 130$ \\
& & $\mathrm{p}<0,05$ & $\mathrm{p}>0,5 ; \mathrm{p}_{1}<0,05$ \\
\hline The degree of & $1,00 \pm 0,13$ & $2,07 \pm 0,28$ & $1,01 \pm 0,15$ \\
dysbiosis & & $\mathrm{p}<0,01$ & $\mathrm{p}>0,8 ; \mathrm{p}_{1}<0,02$ \\
\hline Elastase, $\mu$-cat/kg & $327 \pm 12$ & $391 \pm 24$ & $345 \pm 16$ \\
& & $\mathrm{p}<0,05$ & $\mathrm{p}>0,3 ; \mathrm{p}_{1}>0,05$ \\
\hline MDA, mmol/kg & $33,0 \pm 1,8$ & $49,6 \pm 3,7$ & $37,2 \pm 0,9$ \\
& & $\mathrm{p}<0,01$ & $\mathrm{p}<0,05 ; \mathrm{p}_{1}<0,05$ \\
\hline
\end{tabular}

Notes: see table 3.

Table 5 presents the results of determining the condition of rats in which reproduced immunodeficiency (ID). It is seen that in these rats significantly increases the serum activity of urease (bacteremia), decreases the activity of lysozyme (suppression of nonspecific immunity) and more than 4 times the degree of dysbiosis.

In the kidneys of rats with ID significantly increases the activity of urease, elastase, MDA content and the degree of dysbiosis, but significantly reduces the activity of lysozyme.

The use of phytogels significantly reduces the level of urease, elastase, MDA and the degree of dysbiosis, but does not significantly affect the activity of lysozyme, leaving it at a low level. No significant difference in the nephroprotective effect of these drugs was found.

\section{DISCUSSION}

The obtained results show that stomatotropic drugs used by oral applications have a nephroprotective effect in various pathological conditions. Stomatotropic therapy has certain advantages over intragastric pathways of treatment and prevention, because it allows the active substances to enter the bloodstream immediately, bypassing the liver, which usually neutralizes a significant amount of them. 
Table 5 - Biochemical parameters of the condition of rats with immunodeficiency (ID), which received oral applications of phytogels: "Kvertulin", "Biotrit", "Dubovy".

\begin{tabular}{|c|c|c|c|c|c|}
\hline \multirow[b]{2}{*}{ Indicators } & \multicolumn{5}{|c|}{ Групи } \\
\hline & $\begin{array}{c}1- \\
\text { Control }\end{array}$ & $2-$ ID & $\begin{array}{c}3- \\
\text { ID+ Kvertulin }\end{array}$ & $\begin{array}{c}4- \\
\text { ID + Biotrit }\end{array}$ & $\begin{array}{c}5- \\
\text { ID+Dubovy }\end{array}$ \\
\hline \multicolumn{6}{|l|}{ Blood serum: } \\
\hline $\begin{array}{l}\text { Urease, } \\
\text { mk-cat/l }\end{array}$ & $0,07 \pm 0,02$ & $\begin{array}{c}0,19 \pm 0,08 \\
\mathrm{p}<0,05\end{array}$ & & & \\
\hline $\begin{array}{l}\text { Lysozyme, } \\
\text { units/liter }\end{array}$ & $196 \pm 12$ & $\begin{array}{l}122 \pm 9 \\
\mathrm{p}<0,01\end{array}$ & & & \\
\hline $\begin{array}{l}\text { The degree } \\
\text { of dysbiosis }\end{array}$ & $1,00 \pm 0,11$ & $\begin{array}{c}4,37 \pm 0,57 \\
\mathrm{p}<0,001\end{array}$ & & & \\
\hline \multicolumn{6}{|l|}{ Kidneys: } \\
\hline $\begin{array}{l}\text { Urease, } \\
\text { mk-cat/kg }\end{array}$ & $0,08 \pm 0,01$ & $\begin{array}{c}0,20 \pm 0,02 \\
\mathrm{p}<0,01\end{array}$ & $\begin{array}{c}0,14 \pm 0,02 \\
\mathrm{p}<0,05 ; \mathrm{p}_{1}<0,05\end{array}$ & $\begin{array}{c}0,16 \pm 0,02 \\
\mathrm{p}<0,05 ; \mathrm{p}_{1}>0,05\end{array}$ & $\begin{array}{c}0,11 \pm 0,01 \\
p<0,05 ; p_{1}<0,05\end{array}$ \\
\hline $\begin{array}{l}\text { Lysozyme, } \\
\text { units/kg }\end{array}$ & $5110 \pm 40$ & $\begin{array}{c}4480 \pm 190 \\
p<0,01\end{array}$ & $\begin{array}{c}4630 \pm 120 \\
p<0,05 ; p_{1}>0,3\end{array}$ & $\begin{array}{c}4760 \pm 150 \\
p<0,05 ; p_{1}>0,05\end{array}$ & $\begin{array}{c}4590 \pm 120 \\
p<0,05 ; p_{1}>0,3\end{array}$ \\
\hline $\begin{array}{l}\text { The degree } \\
\text { of dysbiosis }\end{array}$ & $1,00 \pm 0,12$ & $\begin{array}{c}2,87 \pm 0,21 \\
\mathrm{p}<0,01\end{array}$ & $\begin{array}{c}1,92 \pm 0,12 \\
p<0,05 ; p_{1}<0,05\end{array}$ & $\begin{array}{c}2,15 \pm 0,26 \\
\mathrm{p}<0,05 ; \mathrm{p}_{1}<0,05\end{array}$ & $\begin{array}{c}1,52 \pm 0,18 \\
p<0,05 ; p_{1}<0,05\end{array}$ \\
\hline $\begin{array}{l}\text { Elastase, } \\
\mathrm{mk} \text {-cat/kg }\end{array}$ & $427 \pm 13$ & $\begin{array}{c}489 \pm 27 \\
p<0,05\end{array}$ & $\begin{array}{c}435 \pm 12 \\
\mathrm{p}>0,3 ; \mathrm{p}_{1}<0,05\end{array}$ & $\begin{array}{c}438 \pm 21 \\
\mathrm{p}>0,3 ; \mathrm{p}_{1}>0,05\end{array}$ & $\begin{array}{c}433 \pm 4 \\
\mathrm{p}>0,3 ; \mathrm{p}_{1}<0,05\end{array}$ \\
\hline $\begin{array}{l}\mathrm{MDA}, \\
\mathrm{mmol} / \mathrm{kg}\end{array}$ & $21,0 \pm 1,7$ & $\begin{array}{c}28,2 \pm 1,2 \\
\mathrm{p}<0,05\end{array}$ & $\begin{array}{c}21,8 \pm 0,9 \\
p>0,3 ; p_{1}<0,05\end{array}$ & $\begin{array}{c}20,2 \pm 0,7 \\
\mathrm{p}>0,3 ; \mathrm{p}_{1}<0,05\end{array}$ & $\begin{array}{c}21,9 \pm 1,0 \\
\mathrm{p}>0,3 ; \mathrm{p}_{1}<0,05\end{array}$ \\
\hline
\end{tabular}

Notes: see table. 3 .

The results of the study indicate that different phytogels have significant differences in their action on biochemical markers of the kidneys, but their common property is to reduce the markers of inflammation (elastase activity and MDA content), reduce bacterial insemination (urease activity) and the degree of dysbiosis. At the same time, all phytogels increase (restore) the activity of lysozyme as one of the factors of nonspecific immunity.

The therapeutic effectiveness of various phytogels largely depends on the characteristics of the pathology. Thus, the phytogel "Kvertulin" was much more active in dysbiotic syndrome than in experimental immunodeficiency (in terms of antielastase and lysozyme-restoring activity). Phytogel "Biotrit" was a much stronger lysozyme-restoring agent in TPSO intoxication than in immunodeficiency.

After recalculation of the action of phytogels per $1 \mathrm{~g}$ of gel or $1 \mathrm{mg}$ of active substance (in our preparations such a substance is quercetin or the sum of polyphenolic compounds) (Table 6) it is seen that the greatest anti-elastase activity has phytogel "Kvertulin", and the greatest lysozyme-reducing activity has phytogel "Biotrit". 
Table 6. Specific anti-elastase (AE) and lysozyme-reducing activity (LRA) of phytogels ( $\Delta \%$ $\mathrm{A} / \mathrm{g}$ gel and $1 \mathrm{mg}$ polyphenols)

\begin{tabular}{|l|c|c|c|c|c|}
\hline \multirow{2}{*}{ Phytogel } & \multirow{2}{*}{ Pathology } & \multicolumn{2}{c|}{ AE } & \multicolumn{2}{c|}{ LRA } \\
\cline { 3 - 6 } & & g of gel & $\mathrm{mg}$ & g of gel & $\mathrm{mg}$ \\
\hline Kvertulin & DS & 16,46 & 3,29 & 8,50 & 1,700 \\
\hline Kvertulin & ID & 0,55 & 0,11 & 0,16 & 0,032 \\
\hline Biotrit & TPSO & 0,59 & 0,12 & 10,79 & 2,110 \\
\hline Biotrit & ID & 0,52 & 0,10 & 0,31 & 0,062 \\
\hline Dubovy & ID & 0,57 & 0,12 & 0,12 & 0,024 \\
\hline
\end{tabular}

Notes: DS - dysbiotic syndrome, ID - immunodeficiency, TPSO - thermoperoxide sunflower oil.

\section{Conclusions}

1. Oral applications of phytogels, which contain antioxidants and antidisbiotics, have a nephroprotective effect.

2. The most effective anti-inflammatory and antidisbiotic drug was the phytogel "Kvertulin", and the most effective lysozyme-restoring drug was the phytogel "Biotrit".

\section{REFERENCES}

1. Stepan VT. Therapeutic and prophylactic effects of the mucous-adhesive gel "Kvertulin" on the kidneys of rats treated with oral applications of peroxide sunflower oil. Dentistry Bulletin. 2019; 10 (special issue): 31-37. (in Ukrainian)

2. Stepan VT. Influence of Dubovy phytogel on the kidney condition of rats treated with oral applications of peroxide sunflower oil. Surgery of Donbass.2019; 8(2): 50-55. (in Ukrainian)

3. Stepan VT. The effect of oral applications of phytogel "Kvertulin" on the biochemical parameters of the kidneys of rats with experimental dysbiotic syndrome. Bukovynian Medical Bulletin. 2020; 24(3(95): 102-107. (in Ukrainian)

4. Stepan VT. Renoprotective action of mucous-adhesive phytogel "Biotrit" in rats, treated with oral application peroxide sunflower oil. Journal of Education, Health and Sport. 2020; 10(11): 89-95.

5. Levitsky AP. Stomatogenic endotoxinemia. Journal of the National Academy of Medical Sciences of Ukraine. 2013; 19(4): 490-493. (in Russian)

6. Levitsky A. P. The use of antidysbiotic preparations in dentistry. Dentistry Bulletin. 2014; 4(89): 89-92. (in Russian) 
7. Levitsky AP, Demyanenko SA, Tsiselskiy YuV. The antimicrobic function of liver. Odessa, KP OGT, 2011:141. (in Russian)

8. Levitsky AP, Makarenko OA, Selivanskaya IA [and others]. «Querthulin», Vitamin P, prebiotic, hepatoprotector.Odessa, KP OGT, 2012: 20. (in Russian)

9. Levitsky AP. Inulin as food for bacteria and medicine for people. Odessa, KP OGT, 2003: 28. (in Russian)

10. Demyanenko SA. Mucoprotective and hepatoprotective properties of wheat germ. Dentistry Bulletin. 2008; 5-6: 10-14. (in Russian)

11. Levitsky AP, Makarenko OA, Khodakov IV [and others]. Hepatoprotective properties of polyphenols substances of Oak extract. Journal of Education, Health and Sport. 2016; 6(11): 537-547.

12. Stepan VT, Pustovoyt IP. The effect of phytopreparations on the biochemical parameters of the kidneys of rats with prednisolone immunodeficiency. Bulletin of Marine Medicine. 2015; 2(67): 87-93. (in Ukrainian)

13. Levitsky AP. Gozhenko AI, Stepan VT [and others]. Biochemical markers of inflammatory-dystrophic and dysbiotic processes in the kidneys of rats in experimental pathology: guidelines. Odessa, 2020: 17. (in Ukrainian)

14. Truhacheva NV. Mathematical Statistics in biomedical research using application package Statistica. Moskow, GJeOTAR-Media, 2012: 379. (in Russian) 